\title{
The Mediating Effects of Service Charge Transparency on the Relationship between Corporate Social Responsibility and Customer Behaviour in Hong Kong's Retail Banking Sector
}

\author{
Canon Tong \\ International Graduate School of Business \\ University of Newcastle,Callaghan NSW, Australia \\ E-mail: canon.tong@gmail.com \\ Anthony Wong \\ Newcastle Graduate School of Business \\ University of Newcastle,Callaghan NSW, Australia \\ E-mail: anthonywong628@yahoo.com \\ Steven Leung \\ Newcastle Graduate School of Business \\ University of Newcastle,Callaghan NSW, Australia \\ E-mail: shusum.leung@uon.edu.au
}

Received: December 7, 2012 Accepted: December 24, 2012

doi:10.5296/ber.v3i1.2801 URL: http://dx.doi.org/10.5296/ber.v3i1.2801

\begin{abstract}
The collapse of substantial numbers of large multinational banking corporations in recent years has prompted regulatory authorities to raise both disclosure and transparency requirements on banks. Banking customers have also called for additional protection against unconscionable
\end{abstract}


practices, and for greater transparency and product information. The literature reveals that transparency positively influences customer behaviour. However, the mediating effect of service charge transparency on the relationship between corporate social responsibility and customer behaviour is a neglected topic. The findings in this research revealed that corporate social responsibility has a positive and significant influence on service charge transparency, customer repurchase intention and word-of-mouth intention. The results also confirmed that service charge transparency has a positive and significant influence on customer repurchase intention and word-of-mouth. Furthermore, they revealed that service charge transparency plays a mediating role in the respective relationships between corporate social responsibility and the two dimensions of consumer behaviour, customer repurchase intention and word-of-mouth intention.

Keywords: Corporate Social Responsibility, Service Charge Transparency, Repurchase Intention, Word-of-mouth Intention

\section{Introduction}

Fallout from the collapse of the Lehman Brothers prompted regulatory authorities in Hong Kong to raise both disclosure and transparency requirements for banks (Ewins, Husted, Lee and Woo, 2010). Customers have also called for additional protection against unconscionable practices, particularly greater transparency with respect to service charges and product information (Ewins et. al., 2010; Matzler, Wurtele and Renzl, 2006). An increasingly stringent and competitive environment is forcing retail banks to re-examine their pricing practices and disclosure policies (Gabaix and Laibson, 2006; Chiu, 2003). Transparency initiatives, especially those relating to the provision of complete product information and pricing schemes, are a first and welcome step in strengthening customer trust (Hultman and Axelsson, 2007). After all, trust is the platform upon which all mutually beneficial relationships are built (Morgan and Hunt, 1994).

\subsection{Background of the Study}

Hong Kong is China's number one financial hub and is one of the most successful economies in Asia (China Daily, 2010). According to China Briefing (2011), "The World Economic Forum, a Swiss non-profit best known for its annual meeting in Davos, rates 60 countries and regions in its Financial Development Index based on several financial indicators, including financial access, business environment, banking and financial services, transparency, institutional environment, non-banking financial services and financial markets" and Hong Kong's ranking jumped from No.4 in 2010 to No. 1 in 2011. Hong Kong's rapid growth is attributable to mainland China's support, well developed legal, tax, financial and banking systems, skilful and hardworking population, and most importantly, its free market economy, international trade and finance (China Daily, 2010).

Hong Kong also has an excellent banking system, well regulated by the Hong Kong Monetary Authority performing the role of central bank. Over the past decade, Hong Kong was able to increase its integration with mainland China through trade, tourism, and financial links, and is 
one of the very few authorized RMB trade settling facilities outside China (China Daily, 2010). Seventy-three out of the world's 100 largest banks have their operations or representations in this city-state. Hong Kong has the largest volumes of external transactions with the best banking regulations in Asia (KPMG, 2012). There are 145 licensed banks, 27 restricted license banks and 28 deposit taking companies in Hong Kong, making a total of 200 authorized banking institutions, out of which 181 are owned by entities from 29 countries (Janus Corporate Solutions, 2012).

The Hong Kong retail banking sector's operating profit for the first three quarters of 2011 rose by $22.2 \%$ compared with the same period of the previous year, indicating a strong growth in this sector. The quality of residential mortgage lending continues to improve since the peak recorded in 2008. The total loans and customer deposits increased by $2.5 \%$ and $1.0 \%$, respectively in the third quarter of 2011 resulting in an overall quarterly loan-to-deposit ratio increase to $56.8 \%$ from $55.9 \%$. Hong Kong dollar deposits fell by $0.8 \%$ while loans grew by $2.4 \%$ in the third quarter, resulting in the quarterly loan-to-deposit ratio rising to $77.9 \%$ from $75.4 \%$ for the second quarter.

Though the Lehman Brothers mini-bond saga raised alarm bells about the impacts of banks shirking their corporate social responsibility (CSR) and failing to maintain high levels of transparency in their conduct of business, there is still a notable lack of attention from both practitioners and researchers to the critical issues of corporate social responsibility and transparency and how these issues affect customer behavior in retail banking. It is of vital importance for banks to be properly managed to deliver quality services, resulting in customer satisfaction and as a result, more favorable customer behavior including customer repurchase intention (CRI) and word-of-mouth intention (WoM) towards their bankers in Hong Kong's competitive banking environment. Within the Hong Kong banking market, competition is deemed to be strong, given that there have been new entrants, mergers, takeovers, and acquisitions over the last two decades (Gabaix and Laibson, 2006). In order to retain customers and to maximize operating profits, bank management need to identify and examine the factors influencing bank customer behavior.

From the previous studies, information disclosure and transparency are found to have positive influences on customer behavior, but the mediating effect of service charge transparency (SCT) on the relationship between corporate social responsibility and customer behavior is a much neglected topic of research. This research fills this void by developing a research framework to empirically test the relationships with data collected from retail banking customers in Hong Kong. The research had two objectives: firstly, to examine the respective levels of influence of corporate social responsibility and service charge transparency on customer repurchase intention and word-of-mouth; and secondly, to investigate the mediating effect of service charge transparency on the relationship between corporate social responsibility and customer repurchase intention and that between corporate social responsibility and word-of-mouth. Corporate social responsibility in this research is defined as the extent to which a bank assumes its economic, legal, ethical and discretionary responsibilities toward the expectation of its stakeholders (Mandhachitara and Poolthong, 2011; Maignan, Ferrell, Hult and Tomas, 1999; Carroll, 1979). 


\section{Literature Review and Hypotheses Development}

As the objectives of this research were to investigate the casual relationships between perceptions of corporate behavior in the form of corporate social responsibility and service charge transparency, and customer behavior in terms of customer repurchase intention and word-of-mouth, the followings identify the gaps in the corporate and customer extant literature to justify the choice of research questions posed for this research.

\subsection{Corporate Behavior}

Many organizations behave well socially because they are concerned that it will impact their performance. Organizational performance is a measure of a firm's ability to compete in the market place and generate profits (Lok, Hung, Walsh, Wang and Crawford, 2005). However, organizational performance is not just financial performance (Skerlavaj, Stemberger, Skrinjar and Dimovski, 2007). Many attempts have been made to develop measurement systems that give a holistic view of an organization's performance. Some systems successfully balance financial and non-financial measures such as operational results (financial) and customer satisfaction (non-financial).

An appropriate measurement system is required to represent and report organizational behaviour through actual and perceived performance measures. Products and services must be delivered that meet customer needs (Walsh, Dinnie and Wiedmann, 2006) and these needs can be categorized as: cost, performance and service, timeliness, and quality (Kaplan and Norton, 1992). Cost or price plays a significant role in the purchasing decision but in service sectors it is difficult to determine price fairness (Hanif, Hafeez, and Riaz, 2010) or 'value for money' (perception), particularly in the finance and banking industry. Customers are also looking for organizations to be socially responsible, however, customers' perceptions as to whether these needs are being met are important determinants of their intentions to continue buying from the same organization and recommending it to others (Brunk, 2010).

\subsection{Corporate Social Responsibility}

Being a good 'corporate citizen' has become important for organizations, due to public's awareness of ethical concerns that emanated from recent high profile business collapses (Brunk, 2010). Although corporate social responsibility reporting has been around for some time, very few organizations have taken it seriously. Since Howard Bowen (1953) made the first contribution to the area, there have been many different definitions and conceptualizations of corporate social responsibility (Mohr, Webb and Harris, 2001; Sen and Bhattacharya, 2001; Zahra and LaTour, 1987; Ullmann, 1985; Carroll, 1979). Due to corporate social responsibility's broad nature and conflicting ideological stances, there is a lack of generally accepted consensus on its definition.

In this research, corporate social responsibility is defined as the extent to which a bank assumes its economic, legal, ethical and discretionary responsibilities toward the expectation of its stakeholders (Mandhachitara and Poolthong, 2011; Maignan et al., 1999; Carroll, 1979). Until lately, corporate social responsibility reporting was only undertaken by large multi-national corporations as a marketing exercise to appease local indigenous people and governments in 
the countries where they operated. Because corporate social responsibility reporting tends to be voluntary in most countries, it is at the discretion of the board and management whether to disclose corporate social responsibility information to the public and investment industry. The situation is changing in cities like Hong Kong. The Oxfam corporate social responsibility Index report of 2009 shows a definite movement to more corporate social responsibility reporting from companies which form the Hang Send Index (31 of the 42 HSI companies responded). Over $70 \%$ of companies voluntarily reported corporate social responsibility to stakeholders. Two banks were in the top ten of the overall corporate social responsibility index; with The Hong Kong and Shanghai Banking Corporation Limited (HSBC) in the number one position at $80 \%$ and Hang Seng Bank with $63 \%$ was tenth.

Previous research reveals a positive association between company valuations and companies that disclose more voluntary information. Larger and dually listed (overseas and local) Chinese companies tend to be more transparent on a voluntary basis than those listed only locally (Cheung, Jiang and Tan, 2010). In recent years, researchers begin to investigating how corporate behavior is being perceived by the society. In spite of the recent significant findings in this sector, further study appears to be necessary (Newholm and Shaw, 2007; Mohr et al., 2001; Sen and Bhattacharya, 2001). Most existing research relating to corporate social responsibility and ethics focuses on the decision-making processes within companies while some research on consumer behavior identified a link between an organization's corporate social responsibility and consumer responses (Madrigal and Boush, 2008; Biehal and Sheinin, 2007; Luo and Bhattacharya, 2006; Berens, Riel, and Bruggen, 2005; De Pelsmacker, Driesen and Rayp, 2005; Mohr and Webb, 2005; Gürhan-Canli and Batra 2004; Lichtenstein, Minnette and Bridgette, 2004; Mohr et al., 2001; Sen and Bhattacharya, 2001; Folkes and Kamins, 1999). Followings provide a discussion of different dimensions of consumer behavior and the development of different hypothesis of this research that relate to corporate social responsibility.

\subsection{Repurchase Intention}

In order to survive and grow, organizations need their customers to have positive experiences and be satisfied customers, remain loyal, advocate on behalf of the service provider, and retain them to continue to repurchase (Walsh et al., 2006). Sprowls and Asimow (1962) developed a customer behavior model and reported that customer satisfaction results in repeat purchases. With high levels of satisfaction, customers can be retained (Kotler, 1994) and acquired (Kaplan and Norton, 1996), which in turn leads to increases in a company's income and profitability as well as market share (Ittner and Larcker, 1998; Ittner and Larcker, 1997; Ittner, Larcker and Rajan, 1997; Banker, Lee, Potter and Srinivasan, 1996; Anderson, Fornell and Lehmann, 1994). Repeat customers are a valuable asset and less costly than acquiring new ones. Most successful businesses have found that the most effective way to retain customers is to provide a service that is above customers' expectations (Nikbin, Armesh, Heydari and Jalalkamali, 2011).

Viewing cost or price from a customer's perspective can be conceptualized as a price continuum based on needs and decisions taken. Starting at the search phase, customers require information on price and quality, therefore making price transparency important. During 
comparison and evaluation, price level, price-quality ratio, and price fairness will become important considerations in a customer's purchasing process. After purchase, customers compare price paid with what they expected the price to be, particularly if the price is known only after a service is provided and already paid for, which occurs frequently with services such as accounting and banking. During and after use, price reliability in terms of whether promises made or implied are kept and whether price changes during a contract are clearly and promptly communicated, is important; hidden costs and price fairness are important aspects that lead to a customer's intention to repurchase. This final stage is dependent on price-quality ratio and price fairness. This key role played by price as a repurchasing determinant is well researched (Sternquist, Byun and Jin, 2004; Voss, Parasuraman and Grewal, 1998; Fornell, Johnson, Anderson, Cha and Everitt-Bryant, 1996).

Keaveney's (1995) study on switching behavior in services revealed that more than half of the customers' switching is because of the perception of poor pricing relative to competitors. Similar findings were obtained in a study of the banking industry; particularly, price perception directly influences the likelihood of switching, customer satisfaction and the intention to recommend to other potential customers (Varki and Colgate, 2001). Given that pricing plays a pivotal role in consumer behavior, it is startling that so few studies have focused on the antecedents and consequences of price satisfaction, particularly corporate social responsibility and transparency (Herrmann, Xia, Monroe and Huber, 2007). Switching intention could be considered the opposite to repurchasing intention. Switching intensions of customers have been well researched, but there is a dearth of literature looking at it from the perspective of repurchase intention (Lam, Shankar, Erramilli and Murthy, 2004).

Thus customer repurchase intention is defined as customers intending to buy from the same supplier or service provider, so long as their recent purchase experience has been satisfactory, to ensure effective use of time and money (Johnson, Barksdale and Boles, 2001; Johnson, Nader and Fornell, 1996). This is especially so for banking customers as the costs and risks involved in switching to a new service provider may create a huge amount of inertia (switching cost) deterring them from switching (Disk, 2008; Lewis and Soureli, 2006). As far as banks are concerned, the efforts and costs to retain an existing customer are much lower than that required to acquire a new one. This explains why increasing customer repurchase intention has always been a top priority for practitioners (Maxham III, 2001). Prior studies revealed that corporate social responsibility activities of a firm can influence customer repurchase intention (Lee and Shin, 2010; Wigley, 2008) but studies in this area are few and there are no published studies set in the northern Asia context, including Hong Kong.

Hypothesis 1: Corporate social responsibility positively affects the repurchase intention of retail banking customers in Hong Kong.

\subsection{Word-of-Mouth Intention}

Improving customer satisfaction not only retains the current customers but also acquires new customers through recommendation by satisfied customers (Kaplan and Norton, 1996). One way satisfied customers make recommendations is by word-of-mouth. Word-of-mouth is a way customers display their satisfaction with products and services through informal networks and 
personal communications for making a purchase decision rather than relying solely on formal channels such as advertising (Bansal and Voyer, 2000). The source of the information has nothing to gain from the receiver of the information, thus a receiver is more accepting of the recommendation from word-of-mouth as the information is usually unbiased (Shiffman and Kanuk, 2007). Receivers of communication by word-of-mouth view information from sources with less skepticism than organization-initiated promotional materials and promotions (Herr, Kardes and Kim, 1991). However, most research on word-of-mouth has been related with product but few of them published on the impact of word-of-mouth for banking services which is more critical because services are intangible (Bansal and Voyer, 2000; Murray, 1997; Brown and Reingen, 1987).

Businesses are attempting to build images that customers recognize and trust. This image draws customers and once these customers sample good service, they are likely to be retained. What firms want is satisfied customers refer other customers. However, image has been described as an attitude (Hirschman, Greenberg and Robertson, 1978), as a subjective knowledge (Boulding, 1956), and as a combination of product characteristics that could be different from the physical product (Erickson, Johansson and Chao, 1984). There appears to be no doubt that company image is one of the core values that lead to business success (Granbois, 1981). Corporate image advertising abounds as a testament to its importance.

A study by Naser, Jamal, and Al-Khatib's (1999) revealed that the image of a bank is one of the most important bank criteria used by customers to select their preferred bank. It has also been shown that brand image is one of the important constructs that explains customers satisfaction (Che-Ha and Hashim, 2007). Company image results from customers' experiences, which then determine customers' perceptions of overall service quality (Aydin and Ozer, 2005). In the same vein, Lu, Zhang, and Wang (2009) suggested that corporate image is a moderator of the relationship between qualities of physical environment, interaction, outcome and service. They argued that customers might tolerate and forgive negative service quality if a firm has a good image. Given the bad press that banks have received, one could argue that their image is somewhat tainted.

Satisfied bank customers could mean that a bank is meeting its customers' expectations (Bloemer, Ruyter, and Peeters, 1998). However, it is how customers feel after they receive services and the attitudes they form that will determine their intention to repurchase and recommend (Jamal and Naser, 2002). Prior research on the satisfaction of bank customers has shown that satisfaction improves customer retention, increases profit, but more importantly increases loyalty to the bank that provided satisfied customers. Westbrook (1987, p.281) defined word-of-mouth as "information communication directed at other consumers about ownership, usage, or characteristics of particular goods and services and/or their sellers." For this study, word-of-mouth is defined as "oral, person-to-person communication between a perceived non-commercial communicator and a receiver concerning a brand, a product, or a service offered for sale" (Arndt, 1967, p.190). Since the importance of corporate image by providing higher level of corporate social responsibility (Demirgüç-Kunt, Detragiache, and Tressel, 2006), this research tried to measure the intention of bank customers to recommend their banks to other potential customers by corporate social responsibility. 
Hypothesis 2: Corporate social responsibility positively affects word-of-mouth intention of retail banking customers in Hong Kong.

\subsection{Service Charge Transparency}

Price or cost has a significant role to play in the purchasing decision of a customer in the service sector, particularly in the finance and banking industry (Hanif et al., 2010). Price or cost fairness is measured as consumers' perception of whether a price for a product or service is reasonable and justifiable (Kukar-Kinney, Xia and Monroe, 2007: Xia, Monroe and Cox, 2004). Prior research revealed that a customer's perception of an acceptable price positively influences his or her satisfaction level and loyalty or repurchase (Martin-Consuegra, Molina and Esteban, 2007). A study by Herrmann et al. (2007) found that customer satisfaction is directly influenced by price perceptions. The way a price or cost is determined and offered (transparency) have a significant impact on customer satisfaction. However, service costs are rarely truly transparent even though they are included in the fine print of contracts and agreements (Matzler et al., 2006).

If perceived quality is more than perceived cost, then customer value is high; but if cost is more than quality, then customer value is low (cost or price-quality ratio concept) (Matzler et al., 2006). Consequently, perceived value (cost or price-quality ratio) is considered very important. Takala, Bhufhai and Phusavat (2006) explained another important factor regarding importance of customer satisfaction: that perceived value both directly and indirectly influences customer satisfaction. In some industries, quality may have a significant positive relationship on customer satisfaction, which may not be the case in other industries (Al-Hawari and Ward, 2006). Banks have come under a lot of scrutiny over costs charged to customers for servicing their accounts and loans (Akerman, 2011), which can be described as service charges. Transparency of fees are important for customers but most times customers using credit cards and other bank services are charged hidden fees of which they were not aware (Kain, 2011).

Following reforms in the USA and UK, the Hong Kong Association of Banks (HKAB), in collaboration with the Hong Kong Monetary Authority (HKMA), introduced reforms for credit cards in January 2011 with a second tranche of reforms announced in June 2011. These changes to how Hong Kong banks treated their credit card customers were in response to the economic downturn and difficulties their customers faced meeting repayment obligations. Part of the reforms were to charge for paying back their debts via other means other than over the counter, such as online or by phone. In addition, customers should not be charged for not using their cards or cancelling their cards (China Daily, 2011). The second round of reforms contained 11 changes to practices, including repayments, increases in credit limits, disclosure, and billing practices. The HKAB aims to promote fair and responsible business practices for credit card issuers. Customers may benefit from measures minimizing interest and increased transparency helps the public to compare products/services among banks and to make right choice (HKMA, 2011a).

A study of compliance with Basel Committee on Banking Supervision - issued the Core Principles for Effective Bank Supervision (BCPs) and bank soundness found that countries where banks are required to accurately and regularly report their financial data to regulators 
and market participants are more highly rated using the Moody's financial strength rating scale (Demirgüç-Kunt, Detragiache, and Tressel, 2006). Hong Kong was part of the sample of this study. One of the measures used was the Kaufman, Kraay, and Mastruzzi (2003) perception of institutional quality index. Along with other indexes, an average bank rating index was constructed that ranked Hong Kong (0.45) just above the average (0.39) of 39 countries, with Ukraine (0.20) ranked the lowest and Sweden the highest (0.73). The UK (0.63) ranked higher than Hong Kong. Given that there are strong regulations governing bank behavior in relation to their practices, how it is that customers and their political representatives are calling for banks to be more transparent about fees and charges. There are two parts to the issue. First, is the "reasonableness" of a service charge. What is a reasonable charge is not an easy thing to measure. The Reserve Bank of India left it to the industry to determine "reasonableness" by setting only a two part criteria to identify basic banking services to which "reasonableness" should apply: nature of transactions and value of transactions. The former criteria included services ordinarily used by individuals and related to deposit and loan accounts, remittance and collection services. The latter related to low value transactions with customers and public up to a ceiling of approximately USD500 (Kain, 2011; Ganguly and Das, 2009).

Much of the extant literature is silent on the issue of service charge transparency in banking (RICS, 2011; 2008). Given that there is a positive relationship between company transparency and market valuation and that voluntary transparency improves this relationship (Cheng, 2010), as well as there has being no clear definition for the banking industry, the issue is worth further study. For this research, service charge transparency is defined as a customer's perception of how non-ambiguous and clear banking charges are. Customers are gaining power over service providers through "access to information, access to more alternatives, more simplified transactions, increasing communication between customers, and a general distrust and resentment among customers" (Urban, 2003 in Matzler et al., 2006, p.219). There is increasing customer demand for open, honest and complete information on services and their costs. Thus, price transparency exists when the retail banking customer can easily get current, non-ambiguous and clearly articulated bank charges effortlessly (Diller, 1997). Together with the review of literature about corporate social responsibility and customer behavior above, three hypotheses were developed as follows.

Hypothesis 3: Corporate social responsibility positively affects service charge transparency perceived by retail banking customers in Hong Kong.

Hypothesis 4: Service charge transparency positively affects repurchase intention of retail banking customers in Hong Kong.

Hypothesis 5: Service charge transparency positively affects word-of-mouth intention of retail banking customers in Hong Kong.

\subsection{Mediating Variables}

Prior studies found that corporate social responsibility has both a direct and indirect impact on customer behavior (Chomvilailuk and Butcher, 2010). In this research, the specific aspects of customer behavior being investigated are repurchase intention and word-of-mouth intention. 


\section{Macrothink}

Business and Economic Research

ISSN 2162-4860 2013, Vol. 3, No. 1

So this research also studied the impact of service chare transparency as a mediating variable on the relationship between corporate social responsibility and repurchase intention and word-of-mouth respectively. It was therefore hypothesized that:

Hypothesis 6: Service charge transparency perceived by retail banking customers in Hong Kong positively mediates the relationship between corporate social responsibility and customer repurchase intention.

Hypothesis 7: Service charge transparency perceived by retail banking customers in Hong Kong positively mediates the relationship between corporate social responsibility and word-of-mouth intention.

\subsection{Research Model}

This research has three constructs. The corporate social responsibility component was adapted from two sources, they are Chomvilailuk and Butcher (2010), and Lacey, Close and Finney (2010). The service charge transparency component was adapted from Matzler et al. (2006). The customer behavior has two dimensions: customer repurchase intention and word-of-mouth. The repurchase intention component was adapted from Maxham III (2001) and Zeithaml, Berry and Parasuraman (1996) whilst the word-of-mouth component was adapted from three sources, comprising Maxham III (2001), Srinivasan, Anderson and Ponnavolu (2002) and Zeithaml, Berry and Parasuraman (1996). Service charge transparency was applied as a significant mediator. The conceptual framework of this research is shown as Figure 1 below.

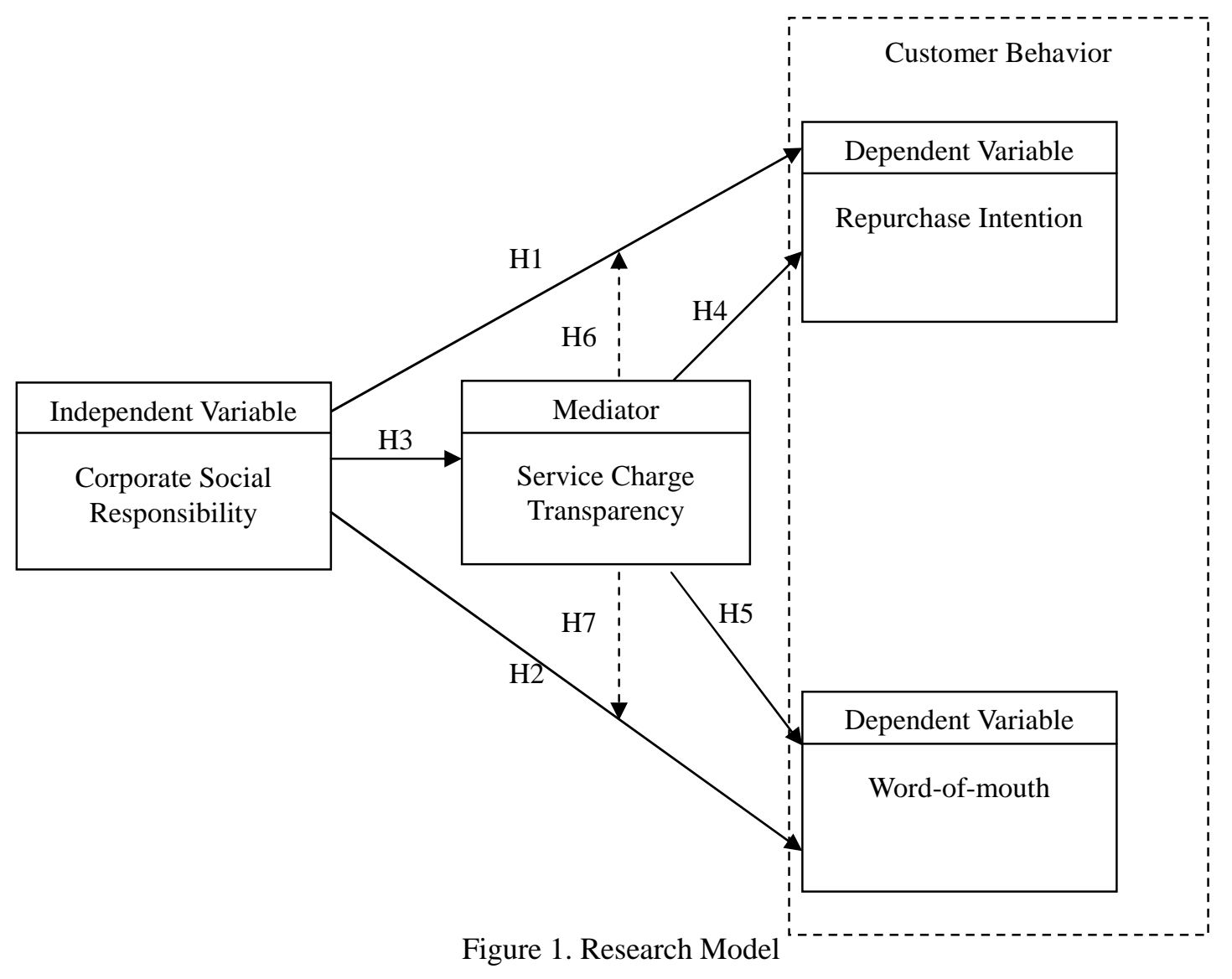




\section{Methodology}

A quantitative research methodology, based on positivist approach, was adopted since the research was grounded in the natural setting of the retail banking industry in Hong Kong.

\subsection{Sample}

The sample frame was retail banking customers in Hong Kong. Convenience sampling technique was used to access potential - Hong Kong citizens aged 18 or above with a personal banking account at the time of the survey. Potential participants were randomly drawn from public domain such as membership lists of professional associations, and the databases of the Hong Kong Trade Development Council (www.hktdc.com).

A total of 3,000 potential participants were drawn from a sample frame derived from public domain in Hong Kong. Previous studies have found that, in so far as quantitative research is concerned, a sample size of 10 times more than the number of question items for the most complex variable should give a good quality of study (Larson, Bjorvell, Billing and Wredling, 2004). However, considering that the sample size of similar online questionnaire research has been larger, ranging from 160 to 219 (Chomvilailuk and Butcher, 2010; Matzler et al., 2006), the sample size of this study was set at about 200, in line with other online studies.

\subsection{Data Collection and Questionnaire Design}

Data collection for this research was carried by using a self-administered online questionnaire survey (Bryman, 2008; Cavana, Delahaye and Sekaran, 2001) because it is cheaper than paper-based questionnaire surveys (Bryman, 2008). A program was set to ensure that only completed and valid responses will be stored in the data file. This ensures that all data collected from an online questionnaire are valid data and hence save the researcher from spending resources and effort on verifying and handling non-complete questionnaires. This can also reduce the introduction of data error by eliminating the manual data key-in process (Bryman, 2008). The questionnaire composed of five parts. The first four parts collected data referring to the three constructs: corporate social responsibility, service charge transparency and the customer behavior which comprised two subordinate constructs, namely customer repurchase intention and word-of-mouth. Each of the constructs and subordinate constructs were measured by multi-item measurement scales. The fifth part collected demographic data from the respondents. The measurement items of the three constructs are shown in Appendix A.

\subsection{Data Analysis}

All questionnaire items of this research were adapted from published articles in peer reviewed journals, content validity and construct validity in which have been validated. However, some minor changes were made to suit the particular context of this research and therefore exploratory factor analysis (EFA) was performed to rule out any possible threat and to further enhance the quality of research (Cavana et al., 2001).

Data analysis began with descriptive statistics to identify the distribution pattern of data. To evaluate the internal consistency and reliability of these multi-item measuring scales, factor analysis was conducted as a data reduction procedure to identify the underlying variables of the 
questionnaire items. Bartlett's test of sphericity and the Kaiser-Meyer-Olkin (KMO) were performed to see whether the data were suitable for factor analysis (Coakes, Steed and Price, 2008; Hair, Black, Babin, Anderson and Tatham, 2005). Cronbach's alpha coefficiencies were used to check the internal reliability of the measuring scales used by each variable. A Cronbach's alpha coefficient of 0.7 or above are regarded as acceptable (Coakes et al., 2008; Hair et al., 2005). Linear regression analysis was conducted to test the hypothesized direct impacts of corporate social responsibility on the other three variables: service charge transparency, customer repurchase intention and word-of-mouth. Linear regression was also conducted to test the direct impacts of service charge transparency on customer repurchase intention and word-of-mouth. Multiple regression analysis, using the mediating test procedures proposed by Baron and Kenny (1986), was conducted to test the mediating effects of service charge transparency on the influences of corporate social responsibility on customer repurchase intention and word-of-mouth respectively.

\section{Findings}

\subsection{Characteristics of the Sample}

Table 1. summarizes the key demographic variables of the research.

\begin{tabular}{|llrr|}
\hline Demographic Variables & Measures & Frequency & Percentage \\
\hline Gender & Female & 140 & $49.1 \%$ \\
\hline & Male & 145 & $50.9 \%$ \\
\hline Marital Status & Single & 178 & $62.5 \%$ \\
\hline & Married & 99 & $34.7 \%$ \\
\hline & Others & 8 & $2.8 \%$ \\
\hline Age & $<25$ & 108 & $37.9 \%$ \\
\hline & $25-34$ & 68 & $23.8 \%$ \\
\hline & $35-44$ & 65 & $22.8 \%$ \\
\hline & $45-54$ & 29 & $10.2 \%$ \\
\hline & $>54$ & 15 & $5.3 \%$ \\
\hline Education Level & Primary & 12 & $4.2 \%$ \\
\hline & Secondary & 72 & $25.3 \%$ \\
\hline & College & 55 & $19.3 \%$ \\
\hline & Undergraduate & 124 & $43.5 \%$ \\
\hline & Postgraduate & 22 & $7.7 \%$ \\
\hline Family Income Level & $<\$ 20,000$ & 138 & $48.4 \%$ \\
\hline & $\$ 20,000-\$ 39,999$ & 100 & $35.1 \%$ \\
\hline & $\$ 40,000-\$ 59,999$ & 32 & $11.2 \%$ \\
\hline & $\$ 60,000-\$ 79,999$ & 8 & $2.8 \%$ \\
\hline & $>\$ 80,000$ & 7 & $2.5 \%$ \\
\hline
\end{tabular}

\subsection{Exploratory Factor Analysis for Reliability Testing}

As certain wording of the questionnaire items, adapted from prior research published in peer reviewed journals had been fine-tuned to meet the needs of this particular study, factor analysis was conducted to see whether the two dimensions of consumer behaviour were loaded into two 
separate variables of repurchase intention (RP) and word-of-mouth (WoM) as expected (Cavana et al., 2001). Further, confirmatory factor analysis was conducted to confirm the validity of the modified questionnaire items of the two remaining variables, i.e. corporate social responsibility (CSR) and service charge transparency (SCT) (Cavana et al., 2001).

Principle component analysis with "Varimax" rotation was conducted using SPSS version 14 on the consumer behaviour related questionnaire items to extract components with eigenvalues greater than 1 since principle component analysis is the most widely used statistical method for factor analysis and data reduction (Hair et al., 2005). Bartlett's test of sphericity and Kaiser-Meyer-Olkin (KMO) were used to check whether the data met the basic assumptions for factor analysis (Coakes et al., 2008; Hair et al., 2005). Table 2 shows that Bartlett's test yields an approximate Chi-square value of 3894.443, with 300 degrees of freedom and is significant $(\mathrm{p}=0.000)$. The KMO measure of sampling adequacy is 0.898 , higher than the minimum acceptable level of 0.6 (Coakes et al., 2008), indicating that the questionnaire items are suitable for exploratory factor analysis.

Table 2. KMO and Bartlett's Test

\begin{tabular}{|l|l|r|}
\hline \multicolumn{2}{|l|}{ Kaiser-Meyer-Olkin Measure of Sampling Adequacy. } & .898 \\
\hline Bartlett's Test of Sphericity & Approx. Chi-Square & 3894.443 \\
\hline & Df & 300 \\
\hline & Sig. & .000 \\
\hline
\end{tabular}

Table 3 shows the factor loading result of exploratory factor analysis: four components were extracted from the exploratory factor analysis as expected. The first component extracted comprises nine questionnaire items of CSR1 to CSR9 with a factor loading between 0.614 and 0.768. The second component extracted comprised five questionnaire items from SCT1 to SCT5 with a factor loading between 0.645 and 0.813 . The third component extracted comprised five questionnaire items from RP1 to RP5 with a factor loading between 0.484 and 0.829. The last component extracted comprised six questionnaire items from WoM1 to WoM6 with a factor loading between 0.468 and 0.889 . As shown in Table 3 , each of the questionnaire items was loaded into one and only one component with factor loading more than 0.4 (Hair et al., 2005).

Table 3. Exploratory Factor Loading

\begin{tabular}{|c|c|c|}
\hline Component & Factor Loading & \\
\hline \multicolumn{3}{|c|}{ Corporate Social Responsibility (CSR) } \\
\hline CSR1 & 0.614 & \\
\hline CSR2 & 0.631 & \\
\hline CSR3 & 0.616 & \\
\hline CSR4 & 0.661 & \\
\hline CSR5 & 0.727 & \\
\hline CSR6 & 0.768 & \\
\hline CSR7 & 0.748 & \\
\hline CSR8 & 0.717 & CSR9 \\
\hline 0.714 & & \\
\hline Service Charg & & \\
\hline
\end{tabular}




\begin{tabular}{|c|c|}
\hline SCT1 & 0.717 \\
\hline SCT2 & 0.813 \\
\hline SCT3 & 0.793 \\
\hline SCT4 & 0.695 \\
\hline Repurchase Intention (RI) & 0.645 \\
\hline RP1 \\
\hline RP2 & 0.823 \\
\hline RP3 & 0.799 \\
\hline RP4 & 0.829 \\
\hline RP5 & 0.817 \\
\hline Word-of-mouth (WoM) & 0.484 \\
\hline WoM1 & \\
\hline WoM2 & 0.468 \\
\hline WoM3 & 0.782 \\
\hline WoM4 & 0.828 \\
\hline WoM5 & 0.887 \\
\hline WoM6 & 0.868 \\
\hline
\end{tabular}

The independent variable, comprising questionnaire items from CSR1 to CSR9, measured a respondent's perception of the corporate social responsibility level of his/her primary bank. The mediating variable, comprising questionnaire items from SCT1 to SCT5, measured a respondent's perception of the service charge transparency level of his/her primary bank. The dependent variable, consumer behavior comprised two components: customers' repurchase intention and word of mouth intention. The customers' repurchase intention dimension, comprising questionnaire items from RP1 to RP5, measured a respondent's intention to reuse the service of his/her primary bank. The word of mouth dimension, comprising questionnaire items from WoM1 to WoM6, measured a respondent's intention to promote or recommend his/her primary bank to others. .

\subsection{Confirmatory Factor Analysis for Reliability Testing}

Principle component analysis was performed on each of the construct to extract components with eigenvalues greater than 1 (Coakes et al., 2008; Hair et al., 2005). Bartlett's test was conducted for each of the constructs and the KMO Measure of Sampling Adequacy of each construct is higher than the minimum acceptable level of 0.6 (Coakes et al., 2008), indicating that the questionnaire items are suitable for factor analysis.

Table 4 below shows factor loading in confirmatory factor analysis, each of the CSR questionnaire items was loaded successfully onto one and only one component with factor loading values between 0.657 and 0.775 , for SCT, each of the questionnaire items was loaded successfully onto one and only one component with factor loading values between 0.689 and 0.850, whilst for each of the questionnaire items of RI were loaded successfully onto one and only one component with factor loading values between 0.606 and 0.858 , finally each of the WoM questionnaire items was loaded successfully onto one and only one component with factor loading values between 0.654 and 0.893 . 


\section{Mll Macrothink}

Business and Economic Research ISSN 2162-4860 2013, Vol. 3, No. 1

Table 4. Confirmatory Factor Loading

\begin{tabular}{|c|c|}
\hline Component & Factor Loading \\
\hline Corporate Social Responsibility (CSR) & \\
\hline CSR1 & 0.657 \\
\hline CSR2 & 0.702 \\
CSR3 & 0.715 \\
CSR4 & 0.693 \\
CSR5 & 0.728 \\
CSR6 & 0.751 \\
CSR7 & 0.775 \\
CSR8 & 0.701 \\
CSR9 & 0.735 \\
\hline Service Charge Transparency (SCT) & \\
\hline SCT1 & 0.775 \\
\hline SCT2 & 0.822 \\
\hline SCT3 & 0.850 \\
\hline SCT4 & 0.714 \\
\hline SCT5 & 0.689 \\
\hline Repurchase Intention (RI) & \\
\hline RP1 & 0.858 \\
\hline RP2 & 0.811 \\
\hline RP3 & 0.842 \\
\hline RP4 & 0.833 \\
\hline RP5 & 0.606 \\
\hline Word-of-mouth (WoM) & \\
\hline WoM1 & 0.654 \\
\hline WoM2 & 0.861 \\
\hline WoM3 & 0.893 \\
\hline WoM4 & 0.891 \\
\hline WoM5 & 0.881 \\
\hline WoM6 & 0.705 \\
\hline & \\
\hline & \\
\hline
\end{tabular}

\subsection{Cronbach's Alpha for Reliability Testing}

Cronbach's alpha tests were conducted to measure the level of consistency among the items in each component (variable) extracted by factor analysis (Coakes et al., 2008; Hair et al., 2005). Table 5 below shows that the four variables have a Cronbach's alpha value ranging from 0.828 to 0.901 , indicating that the data is having an acceptable internal consistency and the measuring scales are reliable for further analysis (Hair et al., 2005; Shin, Collier and Wilson, 2000).

Table 5. Cronbach's Alpha Values of Constructs

\begin{tabular}{|lc|}
\hline Variable & Cronbach's Alpha \\
\hline Corporate Social Responsibility (CSR) & 0.882 \\
\hline Service Charge Transparency (SCT) & 0.828 \\
\hline Repurchase Intention (RI) & 0.842 \\
\hline Word-of-Mouth Intention (WoM) & 0.901 \\
\hline
\end{tabular}




\subsection{Hypotheses Testing}

The seven hypotheses of this research, five relating to direct relationships and two relating to mediating effects, were tested using linear regression analysis.

\subsubsection{Direct Influence of Corporate Social Responsibility}

Hypothesis 1: Corporate social responsibility positively affects customer repurchase intention of retail banking customers in Hong Kong.

Table 6 shows the multiple regression test results with a standardized Beta value of $0.315(\mathrm{~F}=$ 8.110; $\mathrm{p}<0.001)$ which confirm that corporate social responsibility of a retail bank in Hong Kong positively affects the customer repurchase intention of its customers, hence giving support to hypothesis 1.

Table 6. Coefficient of Hypothesis 1

\begin{tabular}{|l|c|c|c|}
\hline Independent Variable & Standardized Beta & F & Sig. \\
\hline Corporate Social Responsibility & 0.315 & 8.110 & 0.000 \\
\hline
\end{tabular}

Dependent Variable: Repurchase Intention

Hypothesis 2: Corporate social responsibility positively affects customer word-of-mouth intention of retail banking customers in Hong Kong.

Table 7 shows the regression test results. The test results, with a standardized Beta value of $0.451(\mathrm{~F}=12.633 ; \mathrm{p}<0.001)$, confirm that corporate social responsibility of a retail bank in Hong Kong positively affects the word-of-mouth of its customers, hence giving support to hypothesis 2 .

Table 7. Coefficient of Hypothesis 2

\begin{tabular}{|l|c|c|c|}
\hline Independent Variable & Standardized Beta & F & Sig. \\
\hline Corporate Social Responsibility & 0.451 & 12.633 & 0.000 \\
\hline
\end{tabular}

Dependent Variable: Word-of-mouth

Hypothesis 3: Corporate social responsibility positively affects service charge transparency perceived by retail banking customers in Hong Kong.

The regression test results shown in Table 8, with a standardized Beta value of 0.337 ( $\mathrm{F}=6.848$; $\mathrm{p}<0.001$ ), confirm that corporate social responsibility of a retail bank in Hong Kong positively affects the service charge transparency perceived by its customers, hence giving support to Hypothesis 3.

Table 8. Coefficient of Hypothesis 3

\begin{tabular}{|l|c|c|c|}
\hline Independent Variable & Standardized Beta & F & Sig. \\
\hline Corporate Social Responsibility & 0.337 & 6.848 & 0.000 \\
\hline
\end{tabular}

Dependent Variable: Service Charge Transparency

4.5.2 Direct Influences of Service Charge Transparency 
Hypothesis 4: Service charge transparency positively affects customer repurchase intention of retail banking customers in Hong Kong.

The regression test results in Table 9, with a standardized Beta value of $0.324(\mathrm{~F}=8.755 ; \mathrm{p}<$ 0.001), confirm that service charge transparency of a retail bank in Hong Kong positively affects the customer repurchase intention of its customers, hence giving support to hypothesis 4.

Table 9. Coefficient of Hypothesis 4

\begin{tabular}{|l|c|c|c|}
\hline Independent Variable & Standardized Beta & F & Sig. \\
\hline Service Charge Transparency & 0.324 & 8.755 & 0.000 \\
\hline
\end{tabular}

Dependent Variable: Repurchase Intention

Hypothesis 5: Service charge transparency positively affects customer word-of-mouth intention of retail banking customers in Hong Kong.

Table 10 shows results of regression test that, with a standardized Beta value of $0.461(\mathrm{~F}=$ 14.055; $\mathrm{p}<0.001$ ), confirm that service charge transparency of a retail bank in Hong Kong positively affects the word-of-mouth of its customers, hence giving support to hypothesis 5 .

Table 10. Coefficient of Hypothesis 5

\begin{tabular}{|l|c|c|c|}
\hline Independent Variable & Standardized Beta & F & Sig. \\
\hline Service Charge Transparency & 0.461 & 14.055 & 0.000 \\
\hline
\end{tabular}

Dependent Variable: Word-of-mouth

\subsubsection{Mediating Effects of Service Charge Transparency}

The three steps approach suggested by Baron and Kenny (1986) and Judd and Kenny (1981) were followed to assess the mediating role of service charge transparency in the relationship between corporate social responsibility and the two dimensions of consumer behavior. First step is to conduct a linear regression analysis with the independent variable predicting the dependent variable. This step was performed and described in section 4.5.1 when the hypothesis 1 and hypothesis 2 were tested and supported. Second step is to conduct a linear regression analysis with the independent variable predicting the mediator. This was performed and described in section 4.5.1 where hypothesis 3 was tested and supported. The last step is to conduct a multiple regression analysis with both the independent variable and the mediator predicting the dependent variable, which is elaborated below.

The difference of coefficients approach proposed by Judd and Kenny (1981) was used to calculate the mediating effect. The Judd and Kenny's (1981) approach involves two regression models: the first regression model is the same as the first step mentioned above which calculates the direct influence of an independent variable on a dependent variable; the second regression model is the same as the third step discussed above which calculates the respective direct influences of an independent variable and a mediator on the a dependent variable.

Hypothesis 6: Service charge transparency perceived by retail banking customers in Hong Kong mediates the relationship between corporate social responsibility and customer 
repurchase intention.

Table 11. shows the multiple regression test results.

\begin{tabular}{|l|c|c|c|}
\hline Independent Variable & Standardized Beta & F & Sig. \\
\hline Corporate Social Responsibility & 0.315 & 8.110 & 0.000 \\
\hline Corporate Social Responsibility & 0.231 & 10.096 & 0.000 \\
Service Charge Transparency & 0.250 & & \\
\hline
\end{tabular}

Dependent Variable: Repurchase Intention

The model summary shown in this table indicates that in the absence of the mediator (service charge transparency), the standardized beta coefficient for the path between corporate social responsibility and customer repurchase intention is 0.315 and significant $(F=8.110 ; p=0.000)$. By adding service charge transparency, the standardized beta coefficient for the path between corporate social responsibility and customer repurchase intention reduces to 0.231 and significant $(\mathrm{F}=10.096 ; \mathrm{p}=0.000)$. The strength of mediating effect is the difference between 0.315 and 0.231 ; meaning that the mediating effect is 0.084 (Judd and Kenny, 1981). As the regression coefficient between the independent variable and the dependent variable is not zero (standardize beta $=0.231$ ), therefore, hypothesis 6 is partially supported.

Hypothesis 7: Service charge transparency perceived by retail banking customers in Hong Kong mediates the relationship between corporate social responsibility and customer word-of-mouth intention.

Table 12 shows the multiple regression test results. The model summary shown in this table indicates that in the absence of the mediator (service charge transparency), the standardized beta coefficient for the path between corporate social responsibility and word-of-mouth is 0.451 and significant $(\mathrm{F}=12.633 ; \mathrm{p}=0.000)$. By adding service charge transparency, the standardized beta coefficient for the path between corporate social responsibility and word-of-mouth reduces to 0.331 and significant $(F=18.939 ; \mathrm{p}=0.000)$. The strength of mediating effect is the difference between 0.451 and 0.331 ; meaning that the mediating effect is 0.120 (Judd and Kenny, 1981). As the regression coefficient between the independent variable and the dependent variable is not zero (standardize beta $=0.331$ ), therefore, hypothesis 7 is partially supported.

Table 12. Coefficient of Hypothesis 7

\begin{tabular}{|l|c|c|c|}
\hline Independent Variable & Standardized Beta & F & Sig. \\
\hline Corporate Social Responsibility & 0.451 & 12.633 & 0.000 \\
\hline Corporate Social Responsibility & 0.331 & 18.939 & 0.000 \\
Service Charge Transparency & 0.354 & & \\
\hline
\end{tabular}

Dependent Variable: Word-of-mouth

\section{Discussion}

The purpose of this research was to investigate the casual relationships between perceptions of corporate behaviour, in the form of corporate social responsibility and service charge transparency, and customer behaviour, measured as customer repurchase intention and 
intention to recommend by word-of-mouth. Using Hong Kong's retail banking industry as the setting, the research gauged retail banking customers' perceptions with respect to different banks' corporate social responsibility and service charge transparency.

Findings from hypothesis 1 suggest that corporate social responsibility in the retail banking industry provides positive catalysts for customer repurchase intention in Hong Kong. However, the respondents perceived a neutral level of customer repurchase intention (mean $=3.77$ ) to their primary banks. The reason behind this perception of retail banks in Hong Kong having a low level of corporate social responsibility may possibly be due to the fact that there is no legal responsibility for the banking industry to report corporate social responsibility. This means that banks convey little or no corporate social responsibility information to the public, resulting in a generally low awareness of it.

Findings from the analyzed data provide support for hypothesis 2 . It is possible that a bank's corporate social performance in the retail banking industry is a positive catalyst for customer word-of-mouth intention and customer repurchase intention in Hong Kong. Banking customers may be influenced by word-of-mouth recommendation from friends and perceive a positive message, such as good brand name, technical support and product knowledge, without studying the detailed banking services before selecting a banking service. However, the respondents also perceived a low level of word-of-mouth $($ mean $=3.24)$ intention toward their bank. The reason for such perception might possibly be consistent with the idea that word-of-mouth is not just interpersonal communication for sharing opinions for buying a product or service. It also might be due to their unsatisfactory experience with the banks (Collier, 1995).

Findings from hypothesis 3 indicates that it is possible that a bank with high corporate social responsibility might improve transparency of service charges voluntarily in order to provide more thorough information as a way of presenting an open and honest image compared to their competitors. It also provides customers with a more convenient way to compare service charges among banks. Corporate social responsibility positively affects banking customers' perception of service charge transparency, however, the respondents perceived that the retail banks in Hong Kong have a low level of service charge transparency (mean = 3.22). The reasons may possibly be that greater service charge transparency may encourage customers to feel comfortable and to save time and cost when searching for suitable banks and making comparisons between alternative offers. However, increased transparency by banks may create frustration and problems that may cause their products to become commoditized (Axelsson and Hultman, 2006).

The analyzed data provides support for hypothesis 4, although respondents perceived that the retail banks in Hong Kong have a low level of service charge transparency. In the service industry, of which retail banking is a part, price fairness may affect corporate image; if prices are seen as unfair, an adverse image is perceived by customers that may lead to switching banks and negative word-of-mouth. One reason that the respondents perceived service charge transparency as positively affecting repurchase intention may be that, if service charges are transparent, customers would be able to make price comparisons more easily to find the best 
deal. Customers may feel uncomfortable if some information is missing and they will suspect that there are hidden additional costs that will only be revealed once they have committed. Secondly, high price-sensitive customers may have greater price information needs and a higher price fairness perception. Once they are satisfied with the information provided, they may show higher attitudinal loyalty through a better satisfaction perception. In Hong Kong's retail banking industry, some customer service managers have built up very strong linked relationships with premium customers. The managers may provide tailor-made consulting services to fit individual needs. By providing customers more and better information, the executives can build up good long-term relationship with customers. Thirdly, customers may perceive banks disclosing more information, such as service cost and service charge transparency, as being more stable and therefore at less risk of failing. They may repurchase banking services from their existing bank even after they have completed a comparison process. They may be willing to trade-off higher service charges for what they perceive to be a more stable bank.

In hypothesis 5, one reason that the respondents perceived service charge transparency as positively affecting customers' word-of-mouth intention may be that if service charges are known and easily comparable, customers may share banking charge, interest rates, and quality of banking service with their relatives and friends in the comparison process. In addition, investors and the media may desire more transparency in the banking industry, especially listed companies, after the recent Lehman Brothers minibond saga. The media may help promote banks that have more transparent corporate governance and who share information with the public and banking customers. Positive word-of-mouth may then be created to build up a better individual bank image.

Findings from the analyzed data provide partial support for hypothesis 6 . One reason may be because customers perceive corporate social responsibility initiatives of banks as voluntary and mainly to benefit their sustainability and corporate image. There is no mandate for banks to be service-charge transparent by enacting corporate social responsibility. In the banking industry, corporate social responsibility reporting is not necessary in order to comply with the rules and regulations of the legal ordinances for banks. From the data analysis, banking customers perceive both a low level of corporate social responsibility and service charge transparency, and a neutral level of repurchase intention in their primary retail bank. This may be because when customers are selecting banking services, corporate social responsibility and service charge transparency is a 'nice to have condition' but not a 'compulsory condition'. Customers may evaluate repurchase intention based on their past experience of satisfaction with regard to price fairness, price and service, and their personal relationship with the banking staff. Secondly, customers may consider corporate social responsibility as a positive contribution to the society and a planning for long-term growth. Customers may, however, consider the benefits to themselves more than to the society at large. They may perceive corporate social responsibility and service charge transparency as part of a code of good practices for banks and as one of the criteria for selecting bank services. Thirdly, customers may remain unchanged and stay with their existing bank. Banks are concerned that their customers may switch to their competitors but customers too may also have concerns if they switch to a new bank. They may 
not want to spend the time to learn and adapt to new bank procedures and staff and therefore may choose to remain with their existing bank.

Findings from the analyzed data provide partial support for hypothesis 7. One reason may be because customers perceive a bank's corporate social responsibility as mainly a gesture to show that they care about the growth of the community and to provide a respectable corporate image. There are no direct influences on service charge transparency in relation to price fairness perceived by customers that enhance word-of-mouth. However, more corporate social responsibility and service charge transparency may help customers believe that banks with proper corporate governance reduce the chances of unethical behaviors, resulting in a positive word-of-mouth for such banks. Another reason might be that customers using banking services from more than one bank may be motivated to memorize the best or worst experiences they encountered in their different banks.

\section{Implications}

This research contributes to multiple aspects of retail banking customer research and has theoretical and practical implications.

Previous studies of bank customers' selection criteria mainly focused on the direct influences of different dimensions, with respect to retail services and banking charges by investigating the interrelated actions and reactions among their constructs. This research is the first to be grounded in corporate social responsibility, service charge transparency, customer repurchase, and word-of-mouth literature, and to develop a research model that describes and hypothesizes the mediating effects of service charge transparency on the relationship between corporate social responsibility and repurchase intention, and word-of-mouth; the model was tested empirically using data collected from retail banking customers in Hong Kong. The major revelation resulting from this approach is the varying degrees of mediating influence of the service charge transparency that corporate social responsibility performances (bank behavior) have and the interaction of these dimensions with the hypothesized mediator on repurchase intention and word-of-mouth.

Unlike previous studies that were conducted in the USA and Europe, this research was conducted in Hong Kong, which is the financial centre of the Asia Pacific Region. The website of the Hong Kong Association of Banks shows that only 24 retail banks provide their bank tariff information via a hyper-link to their corporate website. The Bank Tariff Guide for HSBC Retail Banking and Wealth Management Customers, published in November 2011, states that the intention of the guide is to give customers a clear picture of the fees and charges for the most commonly used services. These charges are applicable only to accounts maintained in the Hong Kong SAR with HSBC reserving the right to introduce charges not included in the guide. It also stated that a $100 \%$ additional charge will be levied on non-HSBC customers on all banking services unless otherwise specified in the guide. Furthermore, the banking fees guides from the Standard Chartered Bank, the Citibank and the Bank of China (Hong Kong) Limited have been checked and, even though they are members of the Hong Kong Association of Banks, no common terminology, presentation format or bank charge formula is made available to customers. All of the guides alert customers to charges that are not mentioned and advise them 
to refer to relevant promotional material available at bank outlets. This reflects the importance for customers to be proactive in relation to fees, as it is not the responsibility or obligation of banks to disclose changes to bank charges. It also means that it is difficult for individual customers to compare charges among different banks.

This research also confirms that both corporate social responsibility and service charge transparency contribute to bank customers' behavior. The contribution of corporate social responsibility to bank customers' behavior has been widely discussed in the literature, but no specific attention has been given to how corporate social responsibility is applied in a real business context. There is no empirical evidence to show that implementation of corporate social responsibility in retail banks improves their business performance. Analysis of the data collected for this research reveals that implementation of corporate social responsibility in retail banks, in the context of the Hong Kong market, is pursued by leveraging positive approaches that affect customers' perception of service charge transparency that in turn positively affects customer repurchase intention and word-of-mouth.

This finding has a practical significance for decision-makers of local retail banking corporations, because for the last two decades the retail banking market has been dominated by global players such as Citibank, DBS and key stated-owned banking corporations from Mainland China. There are four major battlefields: credit cards, premium banking service, tax loans, and mortgage loans. It is clear from the findings of this research that customers of retail banks in Hong Kong have a low level of corporate social responsibility. The amount of information provided to customers is very critical to the score and so providing as much information as possible would result in a higher score. Customers also perceive it as good corporate governance practice if the management style is transparent to the public. Customers perceive transparency of information and service charge transparency as one of the same and the level of trust is increased because customers perceive the bank to be honest. Enhancing transparency of banking practices may improve performance, but when banks have suffered from hard times, providing more information might have a destablizing effect (Nier, 2005).

The findings of this research confirm the direct positive effects of corporate social responsibility and service charge transparency in enhancing customer repurchase intention and word-of-mouth. Previous research revealed that price or cost has a significant role in the purchasing decision of customers, especially in the banking industry. Customer satisfaction is directly influenced by price perception. Once customers are satisfied, they repurchase and recommend the bank by word-of-mouth to friends and relatives. The hypothesis is partly true that in a Chinese-oriented culture such as Hong Kong, people are very sensitive to the disclosure of bank-related information, which may ultimately reveal their wealth to others. Also, it is rare for people to discuss the issue of interest information, because by building up a good relationship with bank executives, customers may have better-than-market (listed) benefits such as premium interest rates, increased loan limits or reduced service charges, all of which cannot be communicated by word-of-mouth.

A major task of this research was to ascertain the mediating role of service charge transparency on the relationship between corporate social responsibility and both repurchase intention and 
word-of-mouth. For decision-makers in Hong Kong banks pursuing corporate social responsibility initiatives and promoting service charge transparency, the efforts and resources put into it may not be adequately compensated for by repurchase intention and word-of-mouth. The low level mediating effect of service charge transparency in the relationship between corporate social responsibility, and repurchase intention and word-of-mouth indicates that 'price transparency' may not be a major issue. Other than that, customers may be concerned more with price fairness and the exact amount of service charges they are required to pay. It would appear that retail banking customers in Hong Kong prefer to shop around and negotiate with different banks for the best terms.

\section{Limitations and Future Research}

The adoption of a positivism paradigm and the use of quantitative research methodology in this research imposed a limitation that there are possible other variables that affect or mediate the hypothesized relationship which may yield different results that may shed further light on the study of corporate social responsibility initiatives and service charge transparency. Further studies which employ both a quantitative and qualitative approach can be conducted to explore other possible relationships. This research may also be limited in terms of its generalizability. As each respondent may use more than one retail bank, the response provided only a 'general' reflection of the perception of bank services. The culturally specific and sector-specific sample may affect the applicability of the findings to other fields, cultures or geographical locations. Further studies should be conducted to ascertain how generalizable the findings are to other jurisdictions or sectors. Another limitation of this research is related to the revelation that the mediator, service charge transparency exerts a partial influence on the relationship between corporate social responsibility and customer repurchase intention and word-of-mouth. This finding may possibly be that the correlations involved are more complicated than originally hypothesized. To address and improve this issue, further study using a mixed approach research can be done to take advantage of triangulation. This research focused only on the banking sector in Hong Kong with the collected data reflecting the perceptions and intentions of randomly selected retail banking customers only. It is limited by its deductive and confirmatory nature: the study investigated the mediating effects of service charge transparency on the relationship between corporate social responsibility and the behavior of retail banking customers in Hong Kong without attempting to reveal the reasons for it. Due to limited time and cost, a cross-sectional nature of this study provides only a snapshot of the relationships between corporate social responsibility and service charge transparency and the behavior of retail banking customers in Hong Kong; it does not reveal changes or trends over time. Although this research reveals that corporate social responsibility and service charge transparency are significant variables relating to the behavior of retail banking customers in terms of their intention to repurchase and recommend by word-of-mouth, further research is required to explore other variables such as customer satisfaction, trust, loyalty, price fairness, customer service standard, and price/service ratio.

\section{References}

Akerman, P. (2011). Bank penalties under scrutiny in federal court case. The Australian, 4 
October 2011,

http://www.theaustralian.com.au/business/financial-services/bank-penalties-underscrutiny-in-federal-court-case/story-fn91wd6x-1226157588103 accessed 17/02/2012.

Al-Hawari, M. and Ward, T. (2006). The effect of automated service quality on Australian banks' financial performance and the mediating role of customer satisfaction. Marketing Intelligence \& Planning. 24(2). 127-147.

http://dx.doi.org/10.1108/02634500610653991

Anderson, E. W., Fornell, C. \& Lehmann, D. R. (1994). Customer satisfaction, market share and profitability: findings from Sweden. Journal of Marketing. July. 53-66.

Arndt, J. (1967). Word of mouth advertising and informal communication, In Cox, D. (Ed.), Risk taking and information handling in consumer behavior, Boston: Harvard University.

Aydin, S. and Özer, G. (2005). The analysis of antecedents of customer loyalty in the Turkish mobile telecommunication market. European Journal of Marketing, 39(7/8). 910-925. http://dx.doi.org/10.1108/03090560510601833

Banker, R. D., Lee, S. Y., Potter, G. \& Srinivasan, D. (1996). Contextual analysis of performance impacts of incentive compensation. Academy of Management Journal, 93 (August). 920-948.

Bansal, H. S. and Voyer, P. A. (2000), World-of-mouth processes within a services purchase decision context. Journal of Service Research. 3(2). 166-177.

Baron, R. M. and Kenny, D. A. (1986). The moderator-mediator variable distinction in social psychological research: conceptual, strategic, and statistical considerations. Journal of $\begin{array}{llrrr}\text { Personality and Social } & \text { Psychology. } & \text { 51(6). } & \text { 1173-1182. }\end{array}$ http://dx.doi.org/10.1037/0022-3514.51.6.1173

Biehal, G. J. and Sheinin, D. A. (2007). The Influence of Corporate Messages on the Product Portfolio. Journal of Marketing. 71(2). 12-25. http://dx.doi.org/10.1509/jmkg.71.2.12

Berens, G. A. J. M., Riel, C. B. M. van and Bruggen, G. H. van (2005). Corporate associations and consumer product responses: the moderating role of corporate brand dominance. Journal of Marketing. 69(July). 35-48 .

Bhattacharya CB and Sen S, (2004). Doing better at doing good: When, why, and how consumers respond to corporate social responsibility. California Management Review. 47(1). 9-24.

Bloemer, J., Ruyter, K. D. and Peeters, P. (1998). Investigating drivers of bank loyalty: the complex relationship between image, service quality and satisfaction. International Journal of Bank Marketing. 16(7). 276-86.

http://dx.doi.org/10.1108/02652329810245984

Boulding, K. E. (1956). The image: knowledge in life and society. Ann Arbor: University of 
Michigan Press.

Bowen, H. (1953). Social Responsibilities of the Businessman. New York: Harper. One of the seminal works.

Brown, J. J. and Reingen, P. H. (1987). Social ties and word of mouth referral behavior. Journal of Consumer Research. 14(December). 350-362.

Brunk, K. H. (2010). Exploring origins of ethical company/brand perceptions - A consumer perspective of corporate ethics. Journal of Business Research, 63. 255-262. http://dx.doi.org/10.1016/j.jbusres.2009.03.011

Bryman, A. (2008). Social research methods, New York: Oxford University Press.

Carroll B. (1979). A three-dimensional conceptual model of corporate performance. Academy of Management Review. 4(4). 497-505

Cavana, R. Y., Delahaye, B. L. and Sekaran, U. (2001). Applied business research: qualitative and quantitative methods. Milton, Queensland: John Wiley \& Sons.

Che-Ha, N., and Hashim, S. (2007). Brand equity, customer satisfaction and loyalty: Malaysian banking sector. International Review of Business Research Papers. 3(5). 123-133.

Cheung, Y. L., Jiang P. and Tan, W. (2010). A transparency disclosure index measuring disclosures: Chinese listed companies. Journal of Accounting and Public Policy. 29(3). 259-280. http://dx.doi.org/10.1016/j.jaccpubpol.2010.02.001

China Briefing, (2011). World Economic Forum December 15, 2011, Hong Kong Named World's Number One Financial Centre, viewed 15/2/2012.

http://topics.scmp.com/news/china-business-watch/article/Hong-Kong-is-No-1-financial-cent re

China Daily, (2011). Bank association issues guidelines on credit cards, viewed 22/1/2012. http://www.cdeclips.com/en/hongkong/Bank_association_issues_guidelines_on_credit_cards/ fullstory_59201.html

China Daily, (2010). China's Nol financial centre: Hong Kong, 8 February 2010, viewed $14 / 2 / 2012$.

http://www.chinadaily.com.cn/bizchina/2010h1results/201008/02/content11082774.htm

Chiu P. (2003) Hong Kong's banking industry facing keen competition. China perspectives [Online], 46, March-April 2003, viewed $14 \quad$ February 2012. http://chinaperspectives.revues.org/260

Chomvilailuk, R. and Butcher, K. (2010). Enhancing brand preference through corporate social responsibility initiatives in the Thai banking sector. Asian Pacific Journal of Marketing and Logistics. 22(3). 397-418.

http://dx.doi.org/10.1108/13555851011062296 
Coakes, S. J., Steed, L. \& Price, J. (2008) SPSS Version 15.0 for Windows: analysis without anguish. John Wiley \& Sons Australia, Ltd.

Collier DA, (1995). Modeling the relationships between process quality errors and overall service process performance. Journal Service Industry Management. 64(4). 4-19. http://dx.doi.org/10.1108/09564239510096876

Creswell, J. W. (2009). Research design: qualitative, quantitative, and mixed methods approaches, 3rd ed., California, Thousand Oaks: SAGE Publications, Inc.

De Pelsmacker P., Driesen L. \& Rayp G., (2005). Do consumers care about ethics? Willingness to pay for fair-trade coffee. The Journal of Consumer Affairs. 39(2), http://dx.doi.org/10.1111/j.1745-6606.2005.00019.x

Demirgüç-Kunt, A. Detragiache, E. \& Tressel, T. (2006). Banking on the principles: compliance with basel core principles and bank soundness. Policy Research Working Paper 3954, The World Bank, September.

Diller, H. (1997). Price Management in the Sign of Relationship Marketing. The Business. 57(6).749-63.

Disk, A. A. (2008). Demand estimation and consumer welfare in the banking industry. Journal of Banking \& Finance. 32. 1661-1676.

Erickson, G. M., Johansson, J. K. \& Chao, P. (1984). Image variables in multi-attribute product evaluation: country of origin effect. Journal of Consumer Research. 11(2). 694-699.

Ewins, A., Husted, C., Lee, J. \& Woo, J. (2010). The Lehman Aftermath: Hong Kong and Singapore Regulatory Reforms in the Structured Product Markets World. Capital Markets Law Journal. 5(3). 301-323.

Folkes V. and Kamins M. (1999). Effects of information about firms' ethical and unethical actions on consumer's attitudes. Journal Consumer Psychology. 8(3), 243-259. http://dx.doi.org/10.1207/s15327663jcp0803_03

Fornell, C., Johnson, M., Anderson, E. W., Cha, J. and Everitt-Bryant, B. (1996). The American customer satisfaction index: nature, purpose, and findings. Journal of Marketing, 60(4). 7-18.

Gabaix, X. and Laibson, D. (2006). Shrouded attributes, consumer myopia, and information suppression in competitive markets. Quarterly Journal of Economics. 121(2), 505-540.

Ganguly, A. and Das, A. (2009). On service charges of the banks in India. Viewed 17/02/2011 http://www.math.iitb.ac.in/ ashish/workshop/servicecharge.pdf.

Granbois, D. (1981) An integrated view of the store choice/patronage process, in K. B. Monroe (Ed). Advances in Consumer Research, 8, Association for Consumer Research, Ann Arbor, MI, pp.693-695.

Gürhan-Canli, Zeynep and Rajeev Batra (2004). When Corporate Image Affects Product 
Evaluations: The Moderating Role of Perceived Risk. Journal of Marketing Research. 41(2), 197-205.

Hair, J. F., Black, B., Babin, B., Anderson, R. E. and Tatham, R. L. (2005). Multivariate data analysis, Prentice Hall.

Hanif, M., Hafeez, S, \& Riaz, A. (2010). Factors affecting customer satisfaction. International Research Journal of Finance and Economics. 60, 44-51.

Herr, P. M., Kardes, F. R. \& Kim, J. (1991). Effects of word-of-mouth and product-attribute information on persuasion: an accessibility-diagnosticity perspective. Journal of Consumer Research, 17(4), 454-462.

Herrmann, A., Xia, L., Monroe, K. B., \& Huber. F. (2007). The influence of price fairness on consumer satisfaction: an empirical test in the context of automobile purchases. Journal of Product \& Brand Management. 16(1), 49-58.

http://dx.doi.org/10.1108/10610420710731151

Hirschman, E., Greenberg, B. and Robertson, D. (1978). The intermarket reliability of retail image research: an empirical examination. Journal of Retailing. 54(1), 3-12.

HKMA (2011a). Announcement by the Hong Kong Association of Banks to implement the second batch of credit card reform measures. Hong Kong Monetary Authority, 10 June, viewed 18/02/2012.

http://www.info.gov.hk/gia/general/201106/10/P201106100284.htm

HKMA, (2011). Hong Kong Monetary Authority, Quarterly Bulletin, December 2011,

Hong Kong Monetary Authority (2011). Upgrading of Crédit Agricole (Suisse) SA to a licensed bank, viewed 25th July 2011.

Hultman, J. and Axelsson, B. (2007). Towards a typology of transparency for marketing management research. Industrial Marketing Management. 36(5), 627-635.

http://dx.doi.org/10.1016/j.indmarman.2006.04.001

Ittner, C. D. \& Larcker, D. F. (1997). Quality strategy, strategic control systems, and organizational performance. Accounting Organizations and Society, 22(3/4), 293-314. http://dx.doi.org/10.1016/S0361-3682(96)00035-9

Ittner, C. D., Larcker, D. F., and Rajan, M. V. (1997). The choice of performance measures in annual bonus contracts. The Accounting Review, 72(2), 231-255.

Ittner, C. D. and Larcker, D. F. (1998). Are non-financial measures leading indicators of financial performance? An analysis of customer satisfaction. Journal of Accounting Research, $36(3), 1-35$.

Jamal, A. and Naser, K. (2002). Customer satisfaction and retail banking: an assessment of some of the key antecedents of customer satisfaction in retail banking. International Journal of 
Bank Marketing, 20(4), 146-160.

http://dx.doi.org/10.1108/02652320210432936

Janus Corporate Solutions, (2012). Banking industry and major banks in Hong Kong, viewed 15/2/2012.

http://www.guidemehongkong.com/incorporation/banking/hong-kong-banking-industry-over view

Johnson, M., Nader, G. \& Fornell, C. (1996) Expectations, perceived performance, and customer satisfaction for a complex service: the case of bank loans. Journal of Economic Psychology, 17(2), pp.163-82.

Johnson, J. T., Barksdale Jr., H. C. \& Boles, J. S. (2001). The strategic role of the salesperson in reducing customer defection in business relationships. Journal of Personal Selling \& Sales Management, 21(2), 123-135.

Judd, C. M. \& Kenny, D. A. (1981). Process analysis: estimating mediation in treatment evaluations. Evaluation Review, 5(5), 602-619.

http://dx.doi.org/10.1177/0193841X8100500502

Kain, E. D. (2011). Bank of America Rethinking controversial debit card fees. Forbes, 28 October, viewed 14/02/2012.

http://www.forbes.com/sites/erikkain/2011/10/28/bank-of-america-rethinks-its-controversialdebit-card-fees/

Kaplan, R. S. \& Norton, D.P. (1992). The balanced scorecard - measures that drive performance. Harvard Business Review, 70(1), 71-79.

Kaplan, R. S. and Norton, D.P. (1996). The balanced scorecard: translating strategy into action. Boston: Harvard Business School Press.

Kaufman, D., A. Kraay, and M. Mastruzzi (2003). Governance Matters. Working paper \#3106, The World Bank, Washington, DC.

Keaveney, S. M. (1995). Customer behaviour in services industries: an exploratory study. Journal of Marketing. 59(2), 71-82.

Kotler, (1994). Principles of marketing. (6th ed.), Englewood Cliff, NJ: Prentice Hall.

KPMG (2012), Banking, viewed 15/2/2012.

http://www.kpmg.com/CN/en/WhatWeDo/Industries/Financial-Services/Pages/Banking.aspx

Kukar-Kinney, M., Xia, L, Monroe, L. B. (2007). Consumers' perceptions of the fairness of price-matching refund policies. Journal of Retailing. 83(3), 325-337.

http://dx.doi.org/10.1016/j.jretai.2007.03.005

Lacey, R., Close, A. G. \& Finney, R. Z. (2010). The Pivotal Roles of Product Knowledge and 


\section{Macrothink}

Business and Economic Research ISSN 2162-4860 2013, Vol. 3, No. 1

Corporate Social Responsibility in Event Sponsorship Effectiveness. Journal of Business Research. 63(11), 1222-1228. http://dx.doi.org/10.1016/j.jbusres.2009.11.001

Lam, S. Y., Shankar, V., Erramilli, K. M. \& Murthy, B. (2004). Customer value, satisfaction, loyalty, and switching costs: an illustration from a business-to-business service context. Journal of the Academy of Marketing Science. 32(3), 293-311.

http://dx.doi.org/10.1177/0092070304263330

Larson, J., Bjorvell, C., Billing, E. and Wredling, R. (2004). Testing of an audit instrument for the nursing discharge note in the patient record. Scandinavian Journal of Caring Sciences. 18(3), 318-324. http://dx.doi.org/10.1111/j.1471-6712.2004.00288.x

Lee, K. H. and Shin, D. Y. (2010). Consumers' responses to CSR activities: the linkage between increased awareness and purchase intention. Public Relations Review. 36(2), 193-195. http://dx.doi.org/10.1016/j.pubrev.2009.10.014

Lewis, B. R. and Soureli, M. (2006). The antecedents of consumer loyalty in retail banking. Journal of Consumer Behaviour. 5(1), 15-31. http://dx.doi.org/10.1002/cb.46

Lichtenstein, Donald R., Minnette Drumwright, and Bridgette Braig (2004). The effect of corporate social responsibility on customer donations to corporate-supported nonprofits. Journal of Marketing. 68(4), 16-32.

Lok, P., Hung, R. Y., Walsh, P., Wang, P. \& Crawford, J. (2005). An Integrative Framework for Measuring the Extent to which Organizational Variables Influence the Success of Process Improvement Programmes. Journal of Management Studies. 42(7), 1357-1381. http://dx.doi.org/10.1111/j.1467-6486.2005.00547.x

Lu, Y., Zhang, L. and Wang, B. (2009). A multidimensional and hierarchical model of mobile service quality. Electronic commerce research and applications. 8(5), 228-240. http://dx.doi.org/10.1016/j.elerap.2009.04.002

Luo, X. and Bhattacharya C. B. (2006). Corporate Social Responsibility, Customer Satisfaction, and Market Value. Journal of Marketing. 70(4), 1-18.

Madrigal, R. and Boush, D. M. (2008). Social responsibility as a unique dimension of brand personality and consumers' willingness to reward. Psychology and Marketing. 25(6), 538-564. http://dx.doi.org/10.1002/mar.20224

Maignan, I., Ferrell, O.C., Hult, G. \& Tomas, M. (1999). Corporate citizenship: cultural antecedents and business benefits. Journal of the Academy of Marketing Science. 27(4), 455-69. http://dx.doi.org/10.1177/0092070399274005

Mandhachitara R and Poolthong Y, (2011). A Model of Customer Loyalty and Corporate Social Responsibility. Journal of Service Marketing. 25(2), 122-133.

http://dx.doi.org/10.1108/08876041111119840

Marney, J. (1995). Seppling in Toungs. Marketing Magazine. 100(38), 14. 
Martin-Consuegra, D., Molina, A. \& Esteban, A. (2007). An integrated model of price, satisfaction and loyalty: an empirical analysis in the service sector. Journal of Product \& Brand Management. 16(7), 459-468.

http://dx.doi.org/10.1108/10610420710834913

Matzler, K., Wurtele, A. \& Renzl, B. (2006). Dimensions of price satisfaction: a study in the retail banking industry. International Journal of Bank Marketing. 24(4), 216-231. http://dx.doi.org/10.1108/02652320610671324

Maxham III, J. G. (2001). Service recovery's influence on consumer satisfaction, positive word-of-mouth, and purchase intentions. Journal of Business Research. 54(1), 11-24. http://dx.doi.org/10.1016/S0148-2963(00)00114-4

Mohr L. A. and Webb D. J. (2005). The effects of corporate social responsibility and price on consumer responses. The Journal of Consumer Affairs, 39(1), 121-147.

http://dx.doi.org/10.1111/j.1745-6606.2005.00006.x

Mohr L. A., Webb D. J. \& Harris K. E. (2001). Do consumers expect companies to be socially responsible? The impact of corporate social responsibility on buying behaviour. The Journal of Consumer Affairs. 35(1).

Morgan, R. and Hunt, S. (1994). The commitment theory of relationship marketing. Journal of Marketing. 58(3), 20-38.

Murray, K. B. (1997). A test of service marketing theory: consumer information acquisition activities. Journal of Marketing. 55(1), 10-15.

Naser, K., Jamal, A. \& Al-Khatib, K. (1999). Islamic banking: a study of customer satisfaction and preference in Jordan. International Journal of Bank Marketing. 17(3), 135-150. http://dx.doi.org/10.1108/02652329910269275

Newholm, T. and Shaw, D. (2007). Studying the ethical consumer: A review of research. Journal of Consumer Behaviour. 6(5), 253-270. http://dx.doi.org/10.1002/cb.225

Nier E. (2005). Bank stability and transparency. Journal of Financial Stability. 1(3), 342-354. http://dx.doi.org/10.1016/j.jfs.2005.02.007

Nikbin, D., Armesh, H., Heydari, A. \& Jalalkamali, M. (2011). The effects of perceived justice in service recovery on firm reputation and repurchase intention in airline industry. African Journal of Business Management. 5(23), 9814-9822.

http://dx.doi.org/10.5897/AJBM10.1444

Oxfam (2010). Corporate social responsibility survey of Hang Seng Index constituent companies 2009. Hong Kong: Oxfam, viewed 18/02/2012.

http://www.csr-asia.com/download/HS\%20index_eng.pdf

RICS (2008). Service charges in commercial property Code of Practice. (Irish edition), 
London: RICS Business Services Limited

RICS (2011). Service charges in commercial property: RICS code of practice UK, 2nd ed., Coventry: Royal Institute of Chartered Surveyors, viewed 18/02/2012. http://www.rics.org/site/download_feed.aspx?fileID=9649\&fileExtension=PDF

Sen, S. and Bhattacharya C. B. (2001). Does Doing Good Always Lead to Doing Better? Consumer Reactions to Corporate Social Responsibility. Journal of Marketing Research. 38(2), 225-244.

Shiffman, L. G. and Kanuk, L. L. (2007). Consumer Behaviour.(9th ed), Upper Saddle River, NJ: Prentice Hall.

Shin, H., Collier, D. A. \& Wilson, D. D. (2000). Supply management orientation and supplier/buyer performance. Journal of Operations Management. 18(3), 317- 333.

http://dx.doi.org/10.1016/S0272-6963(99)00031-5

Skerlavaj, M., Stemberger, M. I., Skrinjar, R. \& Dimovski, V. (2007). Organizational Learning Culture - The Missing Link between Business Process Change and Organizational Performance. International Journal of Production Economics. 106(2), 346-367. http://dx.doi.org/10.1016/j.ijpe.2006.07.009

Sprowls, R. C. and Asimow, M. (1962). A model of customer behaviour for the task manufacturing corporation. Management Science. 8(3), 311-324.

Srinivasan, S. S., Anderson, R. and Ponnavolu, K. (2002). Customer loyalty in e-commerce: an exploration of its antecedents and consequences. Journal of Retailing. 78(1), pp. 41-50. http://dx.doi.org/10.1016/S0022-4359(01)00065-3

Sternquist, B., Byun, S. E. \& Jin, B. (2004). The dimensionality of price perceptions: a cross-cultural comparison of Asian consumers. International Review of Retail, Distribution and Consumer Research. 14(1), 83-100.

http://dx.doi.org/10.1080/0959396032000154310

Takala, J., Bhufhai, A. \& Phusavat, K. (2006). Proposed verification method for the content suitability of the customer satisfaction survey. Industrial Management \& Data. 107(7), 979-996. http://dx.doi.org/10.1108/02635570610671515

Ullmann, A. (1985). Data in search of a theory: A critical examination of the relationships among social performance, social disclosure, and economic performance of US firms. Academy of Management Review. 10(3), 540-557.

Urban, G.L. (2003). Customer advocacy: is it for you. Cambridge, MA: MIT.

Varki, S. and Colgate, M. (2001). The role of price perceptions in an integrated model of behavioural intentions. Journal of Service Research. 3(2), 232-40.

http://dx.doi.org/10.1177/109467050133004 
Voss, G. B., Parasuraman, A. \& Grewal, D. (1998). The roles of price, performance, and expectations in determining satisfaction in service exchanges. Journal of Marketing. 62(4), 46-61.

Walsh, G., Dinnie, K., \& Wiedmann, K. P. (2006). How do corporate reputation and customer satisfaction impact customer defection? A study of private energy customers in Germany. Journal of Services Marketing, 20(6), 412-420.

http://dx.doi.org/10.1108/08876040610691301

Westbrook, R. A. (1987) Product/consumption-based affective responses and postpurchase processes. Journal of Marketing Research, 24(August), 258-270.

Wigley, S. (2008). Gauging consumers' responses to CSR activities: does increased awareness make cents? Public Relations Review. 34(3), 306-308.

http://dx.doi.org/10.1016/j.pubrev.2008.03.034

Xia, L., Monroe, K. \& Cox, J. (2004). The price is unfair! A conceptual framework of price fairness perceptions. Journal of Marketing. 68(4), 1-15.

Zahra, S. A., \& LaTour, M. S. (1987). Corporate social responsibility and organizational effectiveness: A multivariate approach. Journal of Business Ethics. 6(6), 459-468.

Zeithaml, V. A., Berry, L. L., and Parasuraman, A. (1996). The behavioural consequences of service quality. Journal of Marketing. 60(2), 31-46.

\section{Appendix A: Measuring Items}

Corporate Social Responsibility

\begin{tabular}{|lc|}
\hline CSR1: & $\begin{array}{c}\text { My primary bank is committed to using a substantial portion of its profits to support } \\
\text { community groups }\end{array}$ \\
\hline CSR2: & My primary bank's business practices are better than industry codes of conduct. \\
\hline CSR3: & $\begin{array}{l}\text { My primary bank's reputation for socially responsible behaviour is above the industrial } \\
\text { average. }\end{array}$ \\
\hline CSR4: & My primary bank is very active in supporting environmental activities. \\
\hline CSR5: & My primary bank has shown strong support for preserving Hong Kong's cultural heritage. \\
\hline CSR6: & My primary bank devotes a lot of time and money to help wide sections of Hong Kong. \\
\hline CSR7: & My primary bank is very active in supporting the disadvantaged. \\
\hline CSR8: & My primary bank provides education scholarships. \\
\hline CSR9: & My primary bank is very active in supporting local athletes. \\
\hline Service Charge Transparency \\
\hline SCT1: & $\begin{array}{l}\text { All charge components of the services offered by my primary bank are clear, } \\
\text { comprehensible and understandable. }\end{array}$ \\
\hline SCT2: & $\begin{array}{c}\text { All charge information of the services offered by my primary bank is complete, correct and } \\
\text { frank. }\end{array}$ \\
\hline SCT3: & $\begin{array}{l}\text { All charge information of the services offered by my primary bank is understandable and } \\
\end{array}$
\end{tabular}




\begin{tabular}{|ll|}
\hline \multicolumn{2}{|c|}{ comprehensive. } \\
\hline SCT4: & I am properly informed about the service charges. \\
\hline SCT5: & I know what I pay and what I get. \\
\hline & \\
\hline Customer Repurchase Intention (Customer Behaviour) \\
\hline RP1: & I intend to use my primary bank for my next banking transaction. \\
\hline RP2: & I will continue using my primary bank for banking services. \\
\hline RP3: & Most likely, I will use my primary bank for my next banking transaction. \\
\hline RP4: & I will consider my primary bank my first choice if I need banking services. \\
\hline RP5: & I will do more business with my primary bank in the next few years. \\
\hline
\end{tabular}

\begin{tabular}{|ll|}
\hline \multicolumn{2}{|l|}{ Word-of-mouth (Customer Behaviour ) } \\
\hline WoM1: & I would say positive things about my primary bank. \\
\hline WoM2: & I would recommend my primary bank to anyone who seeks my advice. \\
\hline WoM3: & I would encourage friends to do business with my primary bank. \\
\hline WoM4: & I would recommend my primary bank to my friends. \\
\hline WoM5: & I would recommend my primary bank to my acquaintances. \\
\hline WoM6: & If my friends were looking for banking service, I would tell them to try my primary \\
\hline & bank. \\
\hline
\end{tabular}

\section{Copyright Disclaimer}

Copyright reserved by the author(s).

This article is an open-access article distributed under the terms and conditions of the Creative Commons Attribution license (http://creativecommons.org/licenses/by/3.0/). 